\title{
Comparative effects of stearic acid, calcium and magnesium stearates as dopants in model lipid membranes
}

\author{
O.V.Vashchenko, N.A.Kasian, L.V.Budianska \\ Institute for Scintillation Materials, STC "Institute for Single Crystals", \\ National Academy of Sciences of Ukraine, 60 Nauky Ave., 61001 Kharkiv, \\ Ukraine
}

\section{Received October 25, 2017}

\begin{abstract}
Comparative studies are reported for calcium and magnesium stearates as well as for stearic acid introduced as dopants in model lipid membranes, both individually and in pairs with cycloserine. Membranotropic effects of the dopants were detected on the basis of complex analysis of phase transition parameters obtained by means of differential scanning calorimetry. The individual membranotropic effects increase in order: CaSt $<$ $\mathrm{MgSt}<\mathrm{StA}$. It was established that cycloserine extends the temperature range of the membrane ripple phase, unlike the other substances studied. Joint addition of each stearate with cycloserine resulted in a previously unknown synergic membranotropic effect reflected as additional elevation of phase transition temperatures with a non-additive concentration dependence. The synergic effect grows with dopants concentration and appears more pronounced for pre-transition than for main transition. Meanwhile, no synergic effect was observed for stearic acid with cycloserine, and the joint effects could be ranged as: CaSt $\geq$ MgSt $>$ StA $\sim 0$.

Keywords: differential scanning calorimetry, calcium stearate, magnesium stearate, stearic acid, model lipid membrane, joint action.
\end{abstract}

Проведены сравнительные исследования стеаратов кальция и магния, а также стеариновой кислоты в качестве добавок в модельных липидных мембранах, как индивидуально, так и в парах с циклосерином. Мембранотропное действие добавок характеризовали по влиянию на параметры фазовых переходов модельной мембраны, полученные методом дифференциальной сканирующей калориметрии. Индивидуальное мембранотропное действие возрастает в ряду: CaSt $<\mathrm{MgSt}<\mathrm{StA}$. Установлено, что, в отличие от других изучаемых добавок, циклосерин расширяет температурный диапазон существования складчатой фазы мембраны. Совместное добавление каждого стеарата с циклосерином приводит к синергизму мембранотропного действия, ранее не установленому, дополнительному повышению температур фазовых переходов мембраны с неаддитивной концентрационной зависимостью. Синергический әффект возрастает с увеличением концентрации добавок и более выражен для предперехода, чем для основного фазового перехода. В то же время, для циклосерина со стеариновой кислотой синергический әффект не обнаружен. Таким образом, для исследуемых веществ әффект совместного мембранотропного действия с циклосерином уменьшается в ряду: CaSt $\geq$ MgSt $>$ StA 0.

Порівняльна дія стеаринової кислоти, стеаратів кальцію та магнію як домішок у модельних ліпідних мембранах. О.В.Ващенко, Н.О.Касян, Л.В.Будянська.

Проведено порівняльне дослідження стеаратів кальцію і магнію, а також стеаринової кислоти як домішок у модельних ліпідних мембранах — індивідуально, так і у парах 3 циклосерином. Мембранотропну дію домішок характеризували за впливом на параметри фазових переходів модельних мембран методом диференціальної скануючої калориметрії. 
Індивідуальна мембранотропна дія зростає у послідовності: CaSt $<$ MgSt $<\mathrm{StA}$. Встановлено, що, на відміну від інших досліджених домішок, циклосерін розширює температурний діапазон існування складчастої фази мембрани. Встановлено, що сумісне уведення кожного стеарату з циклосерином приводить до синергізму мембранотропної дії - додатковому підвищенню температур фазових переходів мембрани з неаддитивною концентраційною залежністю. Синергічний ефект зростає зі збільшенням концентрації домішок $\mathrm{i}$ є більш вираженим для передпереходу, ніж для основного фазового переходу. У той же час, для циклосерину зі стеариновою кислотою синергічного ефекту не виявлено. Таким чином, для досліджених речовин ефект сумісної мембранотропної дії з циклосерином зменшувється у послідовності: CaSt $\geq \mathrm{MgSt}>\mathrm{StA} \sim 0$.

\section{Introduction}

Among the novel materials for advanced practical applications, great attention is paid to materials of biological origin with controlled specific supramolecular structure, which are promising for their use in biomedical studies. An example of such objects is model phospholipid membrane. In relationship to the biological effects of drugs and their active ingredients, especially in the case of their joint application, the model membrane as a matrix constitutes a natural intermediary medium bridging the gap between studies of drug interactions in conditions of chemical solutions and in the living cells.

It is commonly known that introduction of any dopant into a matrix material can affect its properties and characteristics, which can be described as individual action of the dopant on the matrix. When the matrix is enriched with two or more dopants, additional effects can arise (named joint effects), resulting from complex physico-chemical interactions between the dopants in the matrix medium. When the matrix is represented by any biological system (biomolecules, tissues, etc.), such effects, both individual and joint, could have biomedical significance. A classic example of such joint effects is the decrease in solubility and/or precipitation under joint dissolution of two substances, which should be taken into account in the development of drug formulations [1, 2].

Model lipid membranes, in particular, multibilayers of $L$ - $\alpha$-dipalmitoylphosphatidylcholine (DPPC), are widely used as matrix medium to study drug action mechanism both in vitro and in silico [3-5]. Generally, the interaction of drugs with membranes is an area of high importance for the pharmaceutical industry when considering the efficacy and safety of their products [6]. Besides, probing the membrane role in drug interactions is critical to a complete understanding of the medical effects of drugs [7]. Though drug-membrane interaction is nowadays a rapidly expanding field of research, the mechanisms of physico-chemical interactions of drug substances in membrane interior still remain "terra incognita", and the available information is scarce [8].

In order to shed some light on this problem, we examined action of calcium stearate, CaSt, and magnesium stearate, MgSt, on model lipid membranes with the aim to compare their individual and joint effects. In fact, CaSt and MgSt are substances with a vast range of industrial usage, viz., as food supplements and drug excipients $[2,9]$. Both these applications involve the stearates entering the human organism with its subsequent biological action. Taken as excipients, they inevitably contact with lipid membranes and could affect drug delivery into living cells [10]. The role of these excipients in therapeutic action of drugs includes, in particular, drug release and bioavailability [11, 12]. Due to their amphiphilic nature and high lipophilicity $(\log P=14.34$ [13]), the stearates are able to incorporate firmly into the membrane interior with their polar parts locating at the membrane interface.

The stearates under study differ only by their cations, i.e. by their polar parts. Both cations $\left(\mathrm{Ca}^{2+}\right.$ and $\left.\mathrm{Mg}^{2+}\right)$ are known to affect phase behavior and hydration characteristics of model phospholipid membranes [14] and of erythrocytes [15]. Lipid membranes have substantial $\mathrm{Ca}^{2+}$-binding capacity, with several types of sites present [16]. On binding to DPPC membrane, $\mathrm{Ca}^{2+}$ is able to coordinate up to 8 lipid molecules [17]. $\mathrm{Mg}^{2+}$ is also able to aggregate the phospholipid molecules [18]. Nevertheless, substantial difference has been noted between action of $\mathrm{Ca}^{2+}$ and $\mathrm{Mg}^{2+}$ in various membrane systems, as reported in [19-21].

We also tested stearic acid (StA) as membrane dopant. StA can be considered as a structural part of stearates incorporating into membrane interior. Besides, StA is widely used as a lubricant, instead of the stearates $[22,23]$. 
Cycloserin, CyS, was chosen as another dopant to testify its joint action with the stearates. CyS is an antibacterial drug with wide action spectrum, which is conventionally formulated with MgSt. The molecule of CyS is small, compact and hydrophilic ( $M=$ 102.09, $\log P=-1.5[24])$, thus providing for its localization near the membrane interface [25] and for possible contacts with polar group of the stearates in the membrane medium. However, no literature data concerning action of CaSt, MgSt and CyS on lipid membranes were found, while such information could be useful for drug formulation and optimization.

\section{Experimental}

Model lipid membranes, in the form of multibilayers with water content $65 \%$ w/w, were prepared using $L$ - $\alpha$-dipalmitoylphoshpatidylcholine, DPPC (Avanti Polar Lipids, USA), as desrcribed in [8]. Calcium and magnesium stearates, CaSt and MgSt (Magnesia $\mathrm{GmbH}$, Germany), stearic acid, StA (NIOPIK, Russia), and cycloserine, CyS (Enamine, Ukraine), were used as dopants to the "matrix" model membrane. The dopants were introduced during membrane preparation in the form of chloroform solutions; chloroform was then evaporated carefully using a concentrator "Concentrator plus" (Eppendorf, USA).

The membranes examined contained one of the individual dopants or pairs, [CyS + CaSt] and [CyS + MgSt]. At fixed total concentration of the dopants, the value of stearates molar fraction, $x_{s t}$, was varied from 0.0 to 1.0 for each pair. The whole range of $x_{s t}$ was under careful consideration because stearate/drug ratio in a tablet could vary by an order of magnitude. Indeed, content of CaSt in a tablet is up to $1 \% \mathrm{w} / \mathrm{w}$, whereas content of MgSt is up to $5 \% \mathrm{w} / \mathrm{w}$ [9]. Taking into account that drug content in a tablet can vary widely, between 0.5 and $80 \% \mathrm{w} / \mathrm{w}$ [8], concentrations of the dopants in the matrix membrane were taken as 2 and $5 \% \mathrm{w} / \mathrm{w}$, both for individual dopants and for the pairs.

Profiles of differential scanning calorimetry (DSC) were obtained for all the systems studied using a microcalorimeter "Mettler DSC 1" (Mettler-Toledo, Switzerland). Three batches of each system were studied to ensure reproducibility. Two cooling-heating scans at $2 \mathrm{~K} / \mathrm{min}$ were performed for each sample in the temperature range of DPPC pre- and main transitions ( 20 to $55^{\circ} \mathrm{C}$ ). Under heating, three thermodynamic phases of DPPC membrane take place in this region: the "ripple" phase follows the "gel" phase and precedes the "liquid crystalline" phase [26, 27].

Basing on DSC profiles, thermodynamic parameters of both phase transitions were obtained, such as temperature $\left(T_{p}, T_{m}\right)$, enthalpy $\left(\Delta H_{p}, \Delta H_{m}\right)$, half-width $\left(\Delta T_{p}{ }^{1 / 2}\right.$, $\Delta T_{m}{ }^{1 / 2}$ ) and hysteresis $\left(h_{p}, h_{m}\right)$. Hysteresis was determined as difference between the corresponding values of $T_{p}$ (or $T_{m}$ ) obtained in heating and cooling scans. DSC1 Star Thermal Analysis System and QTiPlot free software were used for data processing. The experimental data are presented as the averaged value \pm standard deviation for 3 samples.

The cooperativity number of lipids, $C N$, was calculated according to [28] as:

$$
C N=\frac{4 R T_{m}^{2}}{\Delta T_{m}^{1 / 2} \Delta H_{m}}
$$

where $R$ is the universal gas constant.

Estimation of joint effects of two dopants in the membrane was made basing on shifts of the main phase transition temperature $\left(\Delta T_{m}\right)$, as the most representative characteristic of the dopant effect [25]. The parameter of joint action, $J_{A B}$, was calculated according to [29]:

$$
\begin{gathered}
J_{A B}=\frac{1}{n} \sum_{i=1}^{n} \Delta T_{m}^{a d d}-\Delta T_{m}{ }^{\prime}= \\
=\frac{1}{n} \sum_{i=1}^{n}\left(1-c_{i}\right) \Delta T_{m}^{A}+c_{i} \Delta T_{m}^{B}-\Delta T_{m}{ }^{\prime},
\end{gathered}
$$

where $c_{i}$ is the mass fraction of dopant $B$ relative to the total dopants content in the membrane; $\Delta T_{m}{ }^{A}$ and $\Delta T_{m}{ }^{B}$ are the shifts of $T_{m}$ resulting from individual introduction of dopants $A$ or B; $\Delta T^{\text {madd }}$ is hypothetic (molar additive) $\Delta T_{m}$ values under joint dopants introduction; $\Delta T_{m}{ }^{i}$ is the experimentally obtained value for joint dopant introduction; $n-$ the number of systems with various $c_{i}$. In fact, parameter $J_{A B}$ characterizes mean deviation of experimentally obtained $\Delta T_{m}$ values from additivity.

\section{Results and discussion}

Representative DSC thermograms of lipid membranes doped with StA, CaSt, MgSt and CyS are shown on Fig. 1. All the dopants increase $T_{m}$. For StA, the effect observed is in agreement with literature data [30,31] as well as with the concept of hydrophilichydrophobic mismatch $[32,33]$. As men- 
a)
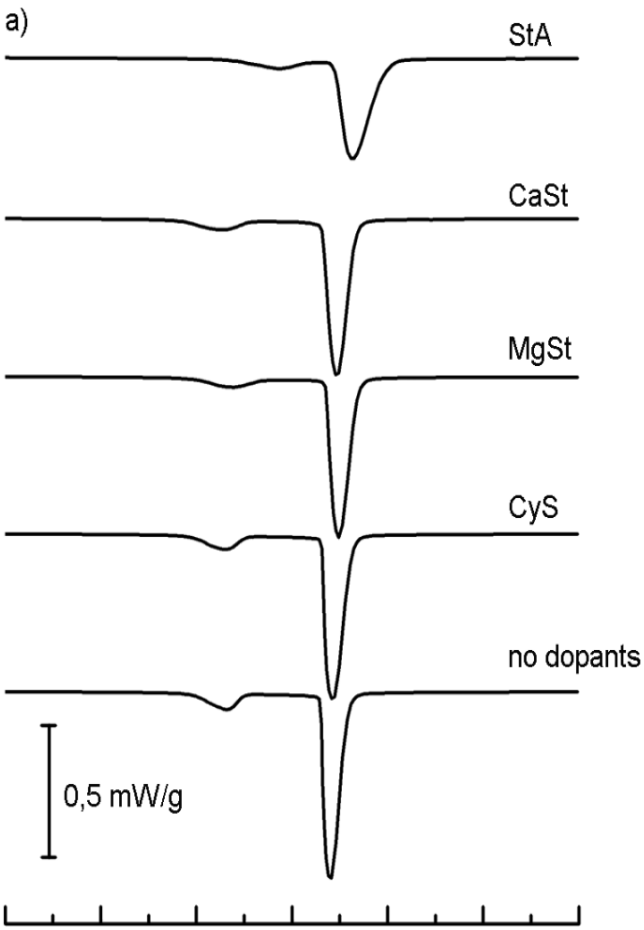

b)

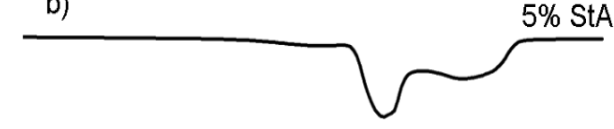

$2 \%$ StA

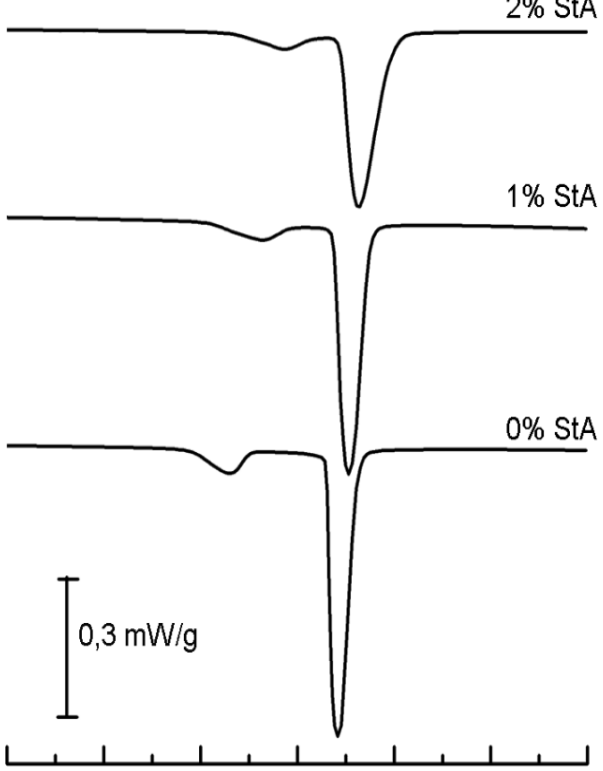

Fig. 1. DSC thermograms of DPPC model membrane with $2 \% \mathrm{w} / \mathrm{w}$ of the dopants (a) and with StA at various concentrations (b) obtained in heating scans.
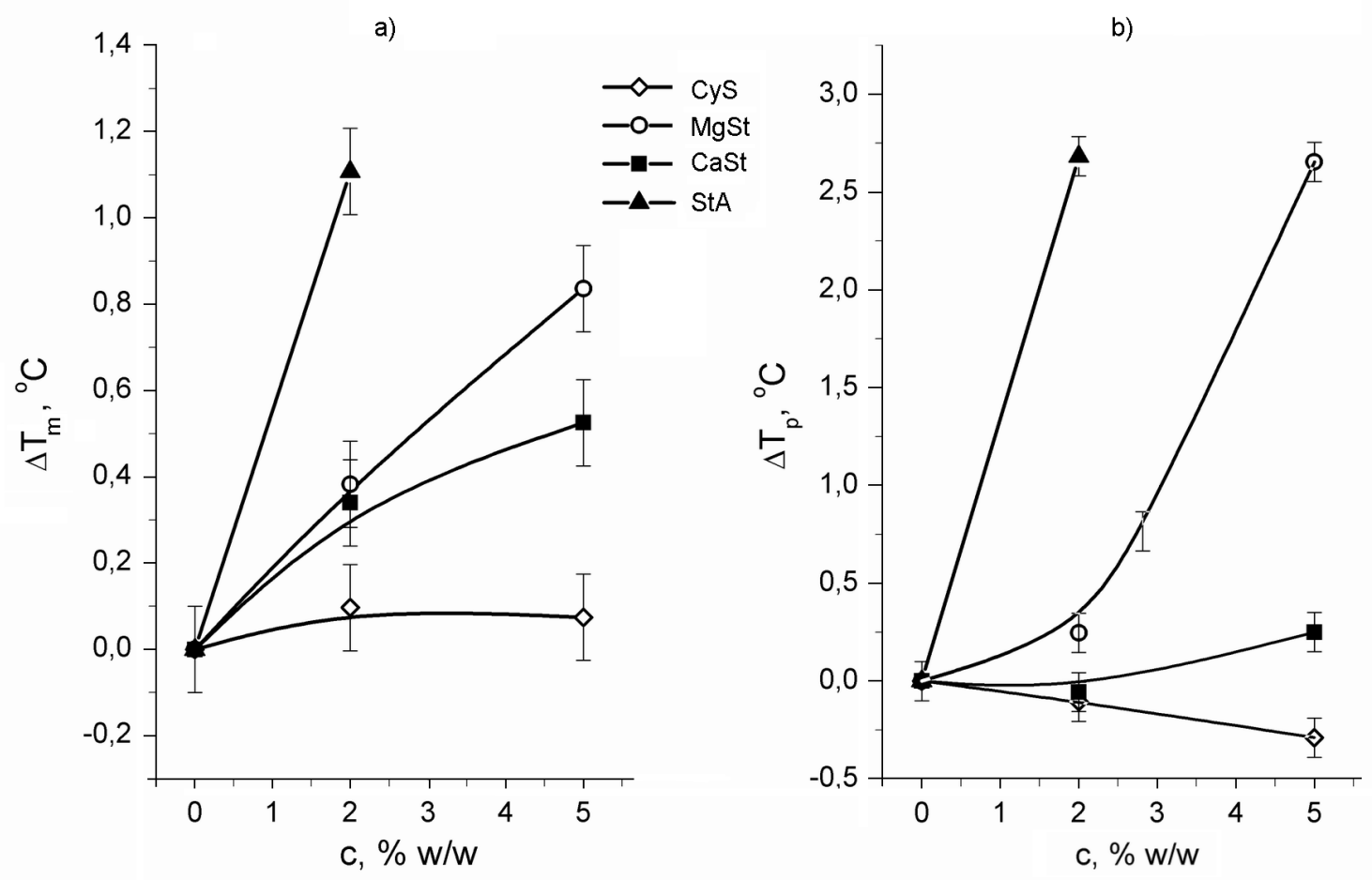

Fig. 2. Shifts of the $T_{m}$ (a) and $T_{p}$ (b) of DPPC membrane with the dopants concentration.

tioned above, there are no available DSC data on membranotropic action of CaSt and MgSt, though long-range effects of $\mathrm{Ca}^{2+}$ and $\mathrm{Mg}^{2+}$ on the packing of the lipid membranes, increasing the order parameter of DPPC alkyl chains were reported [34].

Stearic acid induces lipid phase separation, which is observed as appearance of a 


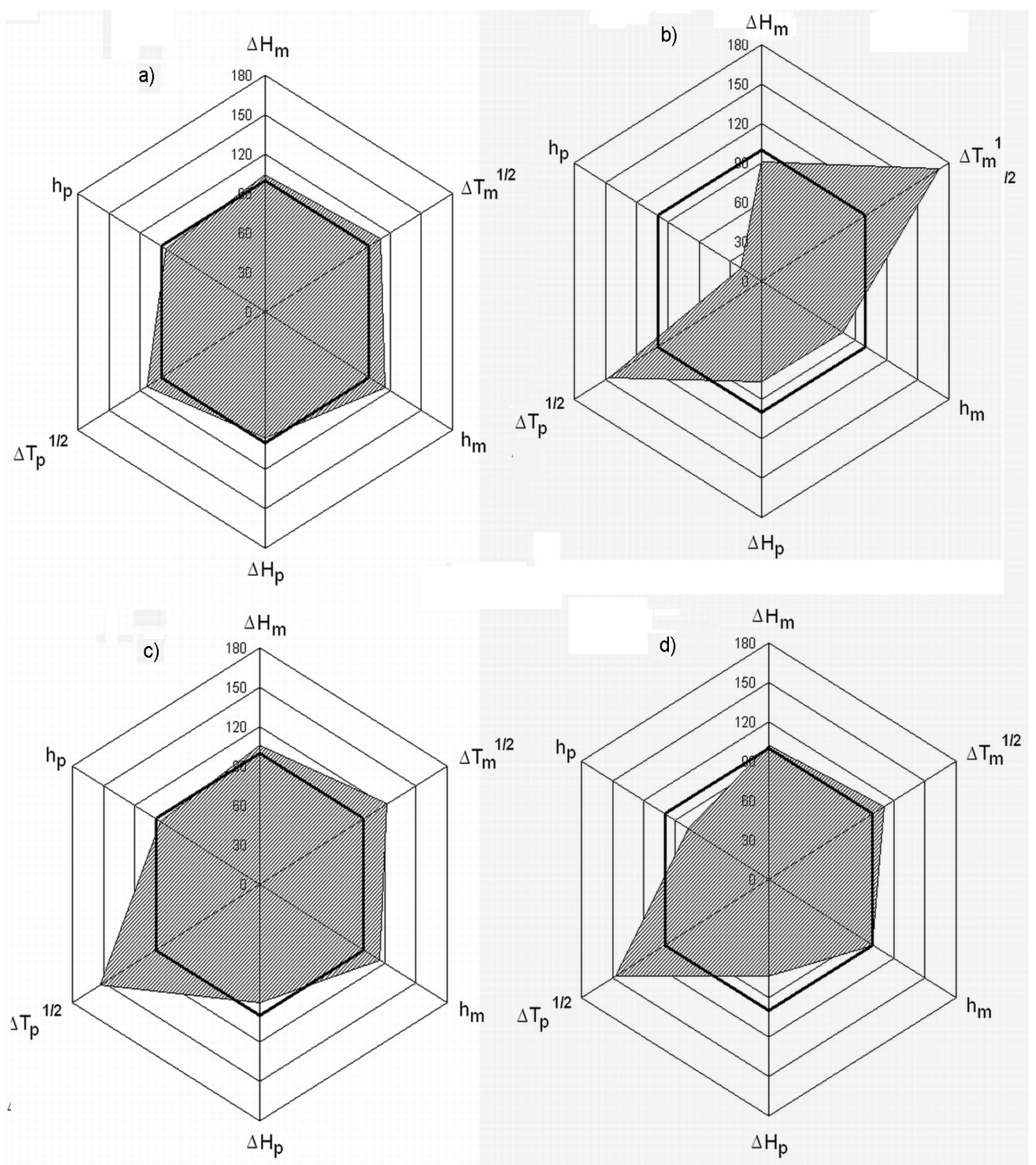

Fig. 3. Thermodynamic parameters of DPPC membrane in the presence of dopants: CyS (a), StA (b), CaSt (c), MgSt (d). Percentage alteration compared to the undoped DPPC membrane (bold line).

high-temperature shoulder on the melting peak, Fig. 1(b). The effect becomes more marked with higher StA concentrations. Basing on the DSC data, concentration dependences of $T_{p}$ and $T_{m}$ were obtained for all dopants, Fig. 2. The more pronounced elevation of the phase transition temperatures was observed for StA $\left(\Delta T_{m}=1.1^{\circ} \mathrm{C}\right.$; $\Delta T_{p}=2.7^{\circ} \mathrm{C}$ at $\left.c_{\mathrm{StA}}=2 \% \mathrm{w} / \mathrm{w}\right)$. As could be seen, $T_{p}$ appears to be more sensitive to dopant addition than $T_{m}$. It should be marked that the effect of CyS on the pre- transition temperature was opposite to that of stearates: CyS decreases $T_{p}$, thus expanding the range of non-lamellar "ripple" phase of DPPC membrane (see "Experimental"). Both stearates and StA favor the "gel" phase at the expense of "liquid crystalline".

The dopants also affected other thermodynamic parameters associated with both phase transitions (Fig. 3). As could be seen, slight enthalpy variations accompany the phase transitions. CyS shows but a small perturbation of the thermodynamic parameters 

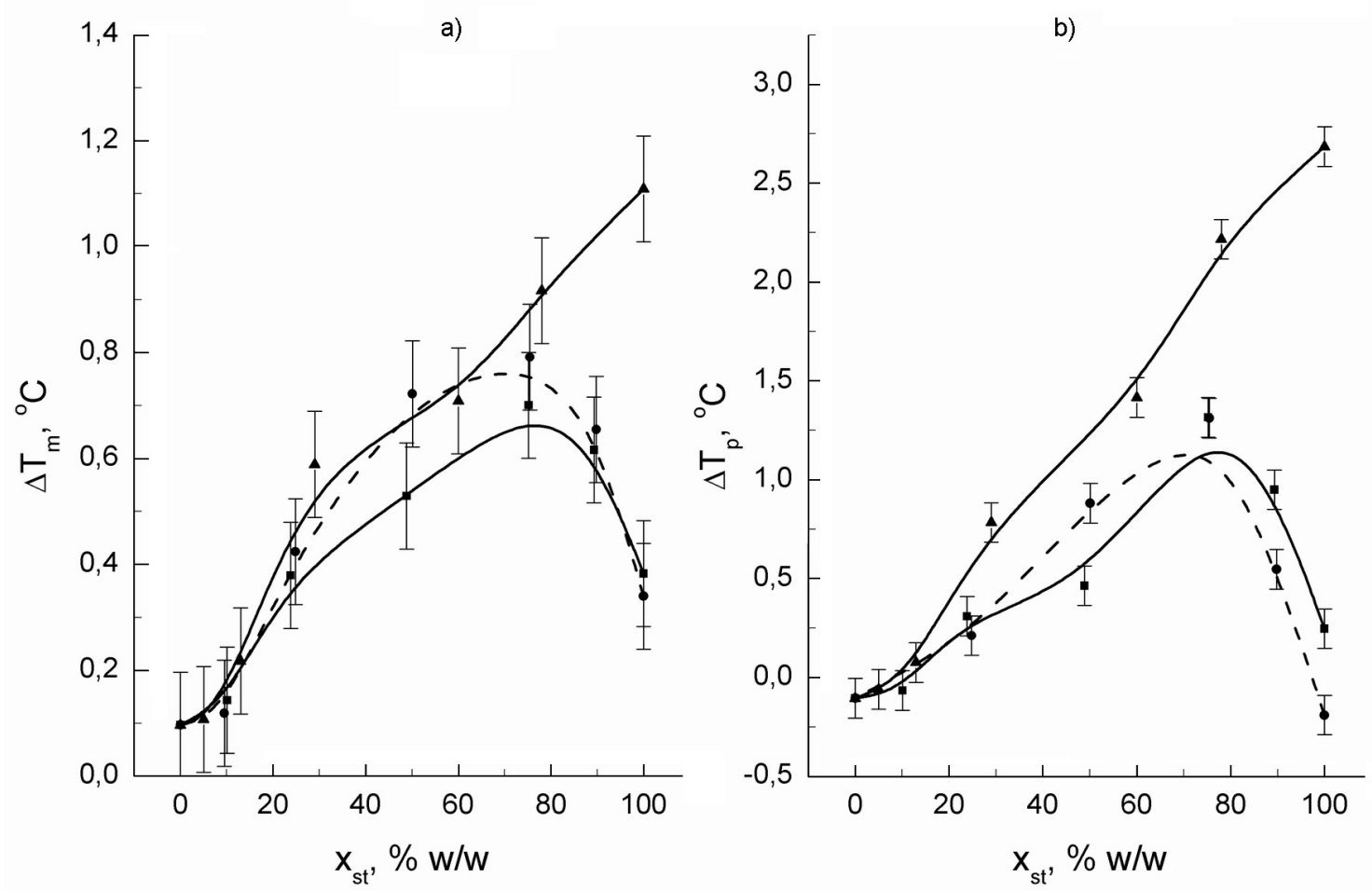

Fig. 4. Shifts of temperatures of the main phase transition (a) and pre-transition (b) of DPPC membrane doped with $2 \% \mathrm{w} / \mathrm{w}$ of [CyS + CaSt] $(0)$

$(\bullet),[C y S+M g S t](\boldsymbol{\square})$ or $[$ CyS + StA] (A).

(within experimental error). The most pronounced effect is observed for StA. It substantially increases both $\Delta T_{p}^{1 / 2}$ and $\Delta T_{m}^{1 / 2}$, which points out to decreasing of cooperativity [26].

Another specific feature of StA is significant reduction of $h_{p}$. Together with the $T_{p}{ }^{1 / 2}$ elevation and the evidences of lipid phase separation (see Fig. 1,b), it bears witness to increasing number of defects in the lipid membrane. The effect of MgSt and CaSt are qualitatively rather similar, but the former is closer to StA action (Fig. 2, Fig. 3). This finding could be understood taking into account that cross-section area of polar part of the dopants studied range as CaSt $>$ MgSt $>$ StA.

Thus, the dopants examined exert certain effect on both interface and interior of the lipid membrane. Though it is too early to explain exactly the mechanism of membranotropic action of stearates, it presumably could include increasing of lipid heterogeneity. Indeed, it is known that $\mathrm{Ca}^{2+}$ ions, as well as fatty acids in the presence of $\mathrm{Ca}^{2+}$, induce permeabilization of lipid membranes due to increasing of lipid heterogeneity [8, 19, 35-37]. For $\mathrm{Mg}^{2+}$ ions, such effect is lower [19].

The next step is to probe joint membranotropic action of the stearates with CyS, as an excipient and active pharmaceutical ingredient, respectively. DSC thermograms of the lipid membrane doped with [CyS + CaSt] or [CyS + MgSt] as function of $\mathrm{x}_{\text {st }}$ (see "Experimental") were obtained. The effect of $T_{m}$ increasing, which was observed for CyS and stearates individually (see Fig. 2(a)), amplified for their mixtures (Fig. 4). The dependences of $T_{m}$ and $T_{p}$ vs. $x_{s t}$ are non-linear with positive deviation from ideality rule (additivity). It represents a characteristic example of the dopant synergism [12].

The reasons of such synergy effect are not fully clear. It results neither from decreasing of the dopants partitioning into the membrane (otherwise, the effect would be reduced) nor from increasing of CyS partitioning (otherwise, behavior of $T_{p}\left(x_{s t}\right)$ would be opposite, see Fig. 1, Fig. 2 (b)). So, the possible origin of the joint effect could consist in increasing of the stearates partitioning into the membrane. Yet another probable synergy mechanism is complex formation between the dopants. Indeed, complex formation between two drugs resulting to antagonism of joint membranotropic action was reported earlier [38]. It is worth noting that behavior of pure binary systems "palmitic acid — stearic acid" [39] differs fundamentally from the effects observed: decreasing of the mixture melting temperature by 6 to $10^{\circ} \mathrm{C}$ is reported. Be- 

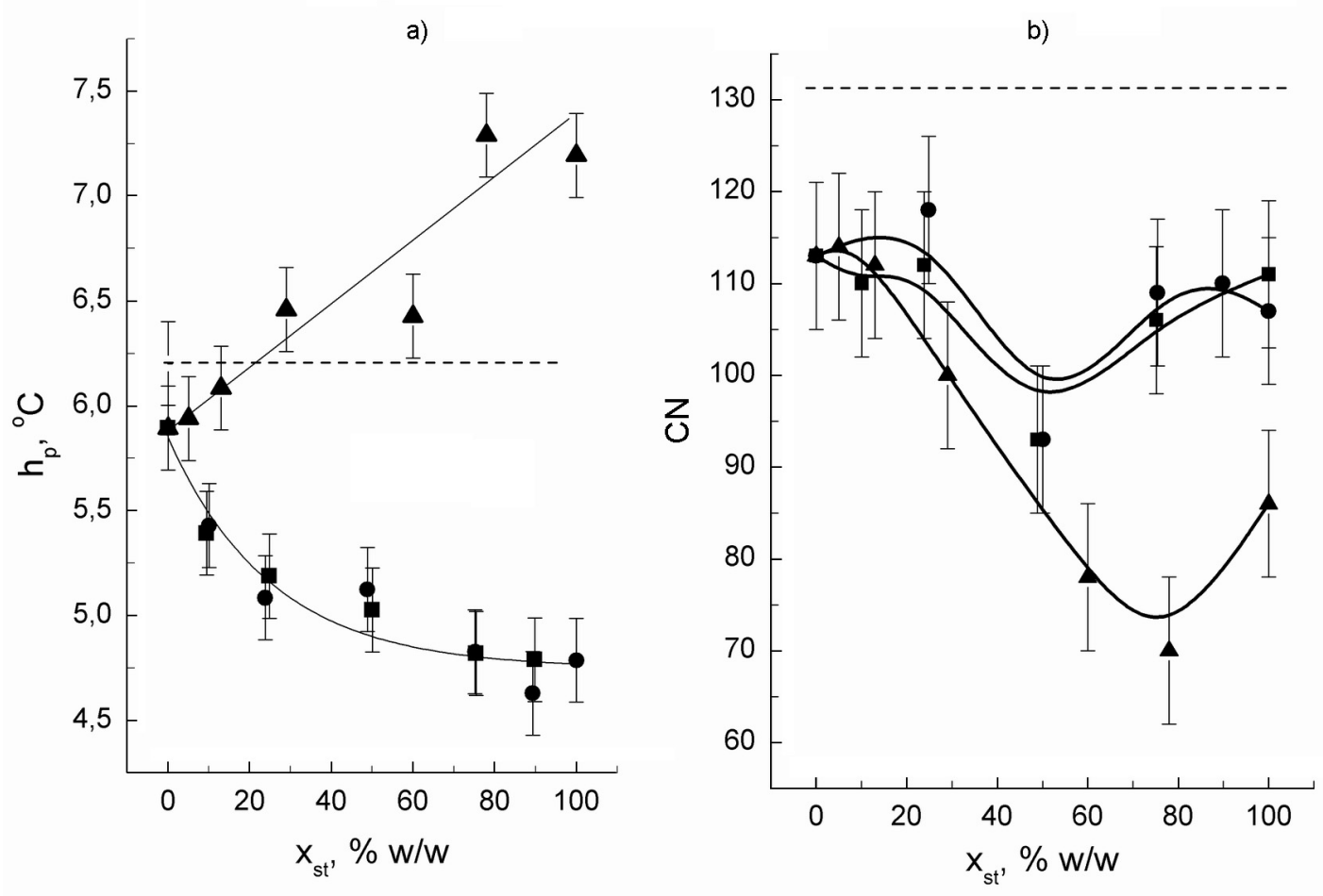

Fig. 5. Hysteresis of the pre-transition (a) and cooperativity of main transition (b) of DPPC

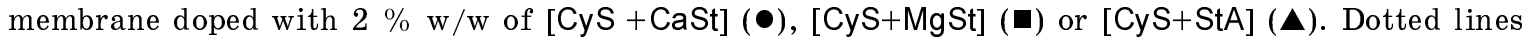
marks the corresponding values for the undoped membrane.

sides, StA is known to induce non-lamellar phase in lipid membranes [31] and sufficiently reduce cooperativity of DPPC membrane [40]. Taking together with the above finding concerning the stabilizing of "ripple" lipid phase by CyS, it allows us to suggest that non-lamellar phase formation could be jointly facilitated. It was also observed that all pairs of dopants had minor influence on $h_{m}$ and $\Delta T_{m}{ }^{1 / 2}$ but substantially decreased these parameters for the pre-transition. In Fig. 5(a), the values of $h_{p}$ are shown. Different behavior should be noted for $h_{p}$ in pairs, which increases with StA concentration and decreases with the concentration of stearates. Cooperative numbers calculated by Eq.(1) are shown in Fig. 5(b). As one can see, parameter $\mathrm{CN}$ is lower for all pairs as compared with pure DPPC, especially for [CyS + StA]. Similar results were obtained for stearates under higher total dopant concentration $(5 \% \mathrm{w} / \mathrm{w})$. Data for StA at this concentration were not obtained because of lipid phase separation (see Fig. 1(b)).

Joint effects were estimated from the $\Delta T_{m}\left(c_{s t}\right)$ plots as outlined in section "Experimental" Eq.2 and summarized in Table 1 (as one can see, [CyS + CaSt] possesses the most prononced joint effect). Then, the pre-transition of the lipid membrane appeared to be more
Table 1. Parameters of joint action of the pairs of dopants in model lipid membranes under various total dopant concentration

\begin{tabular}{||c|c|c|c|c||}
\hline \multirow{2}{*}{ Dopants } & \multicolumn{2}{|c||}{ Main transition } & \multicolumn{2}{c|}{ Pre-transition } \\
\cline { 2 - 5 } & $2 \%$ & $5 \%$ & $2 \%$ & $5 \%$ \\
\hline CyS + CaSt & 0.4 & 0.5 & 0.9 & 2.2 \\
CyS + MgSt & 0.3 & 0.4 & 0.5 & 1.4 \\
CyS + StA & $\sim 0$ & - & $\sim 0$ & - \\
\hline
\end{tabular}

sensitive to both individual and joint dopants action than the main transition. Taking into account the nature of these transitions [26], one can conclude that the dopants cause more perturbing effect on the membrane surface rather than on membrane interface.

To summarize, our data have demonstrated that individual effects of the dopants examined on DPPC membrane are predictable in the scope of our knowledge and available literature data. However, the joint effects, namely, synergism for [CyS +CaSt] or [CyS+MgSt] and its absence for [CyS $+\mathrm{StA}$, could not be predicted, as it is usually for drugs joint action [41]. The underlying molecular mechanism of the joint effects is still far from understanding and therefore is a field of further researches. 


\section{Conclusions}

Effects of calcium stearate, magnesium stearate and cycloserine on phase transitions of DPPC membrane were obtained for the first time under individual and joint introduction. The individual membrano-tropic effects of the stearates and stearic acid appear to be qualitatively similar and increase in the order: CaSt $<$ MgSt $<$ StA. Both stearates and stearic acid increase the temperatures of the main and pretransitions of the membrane. Unlike the other dopants examined, cycloserine extends the temperature range of the membrane ripple phase.

The dopants examined exert larger effect on the membrane interface then on its interior since the pre-transition parameters appeared to be more sensitive to the dopants addition than those of the main transition.

Joint addition of each stearate with cycloserine results in an unexpected synergic membranotropic effect (further increase in both transition temperatures). The synergic effect grows with concentration and appears more pronounced for pre-transition than for main transition. For stearic acid with cycloserine, no synergic effect was observed. So, the joint effect can be ranged as: CaSt $>$ MgSt $>$ StA $\sim 0$.

\section{References}

1. Yu.B.Belousov, K.G.Gurevich, Clinic Pharmacology, Litterra, Moscow (2005) [in Russian].

2. Excipient Applications in Formulation Design and Drug Delivery, ed. by A.S.Narang, S.HS.Boddu, Springer International Publishing Switzerland (2015).

3. J.K.Seydel, M.Wiese, Drug-Membrane Interactions: Analysis, Drug Distribution, Modeling, Wiley-VCH Verlag, Weinheim (2002).

4. M.Lucio, J.L.F.C.Lima, S.Reis, Curr.Med. Chem., 17, 1795 (2010).

5. D.Lopes, S.Jakobtorweihen, C.Nunes et al., Progr.Lip. Res., 65, 24 (2017).

6. A.M.Seddon, D.Casey, R.V.Law et al., Chem. Soc. Rev., 38, 2509 (2009).

7. J.Knobloch, D.K.Suhendro, J.L.Zieleniecki et al., Saudi J. Biol.Sci., 22, 714 (2015).

8. A.O.Sadchenko, O.V.Vashchenko, A.Yu.Puhovkin et al., Biophysics, 62, 570 (2017).

9. Handbook of Pharmaceutical Excipients. ed. by R.C.Rowe, P.J.Sheskey, S.C.Owen., 6th Ed., Pharmaceutical Press, London-Chicago (2009).

10. B.D.Snyder, T.M.Polasek, M.P.Doogue, Austr. Prescr., 35, 85 (2012).

11. Technology and Standardization of Pharmaceuticals, v.2, ed. by V.P.Georgievskij and F.A.Konev, RIREG, Kharkov (2000) [in Russian].

12. A.P.Viktorov, V.G.Peredrij, A.V.Shcherbak. Interaction of Drugs with Foods, Zdorovja, Kyiv (1991) [in Russian].
13. Electronic resource https://chem.nlm.nih.gov/ chemidplus.

14. H.Binder, O.Zschornig, Chem. Phys. Lipids, 115, 39 (2002).

15. R.S.Vest, L.J.Gonzales, S.A.Permann et al., Biophys.J., 86, 2251 (2004).

16. A.Melcrova, S.Pokorna, S.Pullanchery et al., Sci.Rep., 6, 38035 (2016).

17. M.Prudent, M.A.Mendez, D.F.Jana et al., Metallomics, 2, 400 (2010).

18. Z.D.Schultz, I.M.Pazos, F.K.McNeil-Watson et al., J. Phys. Chem. B, 113, 9932 (2009).

19. A.V.Agafonov, E.N.Gritsenko, E.A.Shlyapnikova et al., J.Membr. Biol., 215, 57 (2007).

20. R.Zimmermann, D.Kuttner, L.Renner et al., J.Phys. Chem. A, 116, 6519 (2012).

21. M.O.Anikieieva, S.L.Rozanova, S.Ye.Kovalenko et al., J.Adhes.Sci. Tech., 29, 1039 (2016).

22. J.Wang, H.Wen, D.Desai, Eur.J.Pharm. Biopharm, 75, 1 (2010).

23. J.Li, Y.Wu, Lubricants, 2, 21 (2014).

24. Electronic Resource https://pubchem.ncbi.nlm.nih.gov/compound.

25. A.O.Sadchenko, O.V.Vashchenko, N.A.Kasian et al., Func. Mater., 23, 230 (2016).

26. V.G.Ivkov, G.N.Berestovskiy. Dynamic Structure of Lipid Bilayer, Moscow, Nauka (1981) [in Russian].

27. R.B.Gennis. Biomembranes. Molecular Structure and Functions, New York, Springer-Verlag (1989).

28. R.N.McElhaney, Chem.Phys.Lipids, 30, 229 (1982).

29. O.V.Vashchenko, L.V.Budianska, Biophys. Bull, 36, 11 (2016).

30. R.I.Romao, A.M.Goncalves da Silva, Chem. Phys. Lipids, 131, 27 (2004).

31. J.M.Seddon, R.H.Templer, N.A.Warrender et al., Biochim. Biophys. Acta, 1327, 131 (1997).

32. R.J.Webb, J.M.East, R.D.Sharma, A.G.Lee, Biochemistry, 37, 673 (1998).

33. H.Ohvo-Rekila, P.Mattjus, J.P.Slotte, Biochim. Biophys. Acta, 1372, 331 (1998).

34. R.Zidovetzki, A.W.Atiya, H.de Boeck, Mol. Membr. Biol., 8, 177 (1989).

35. V.F.Antonov, E.V.Shevchenko, Vestn.Ross. Akad.Med.Nauk, 48 (1995).

36. K.N.Belosludtsev, N.V.Belosludtseva, A.V.Agafonov et al., $B B A, \mathbf{1 8 3 8}, 2600$ (2014).

37. K.N.Belosludtsev, N.V.Belosludtseva, K.S.Tenkov et al., BBA, doi: 10.1016/ j.bbamem.2017.09.018 (2017).

38. N.A.Kasian, V.A.Pashynska, O.V.Vashchenko, Mol. BioSyst., 10, 3155 (2014).

39. V.N.Danilin, S.P.Dotsenko, A.V.Martsinkovskiy, S.G.Shabalina, Rus. J.Phys. Chem.A, 75, 18 (2001).

40. P.Losada-Perez, N.Mertens, B.de Medio-Vasconcelos et al., Adv. Cond. Matter Phys., Article ID 479318 (2015).

41. T.-C.Chou, Cancer Res., 70, 440 (2010). 